\title{
ANALISIS PERILAKU OPORTUNISTIK, MEKANISME PENGAWASAN DAN MANAJEMEN LABA PADA PERBANKAN KONVENSIONAL INDONESIA
}

\author{
Ishak Ramli, Stephani \\ Program Studi Magister Akuntansi Fakultas Ekonomi \\ Universitas Tarumanagara, Jakarta \\ Email: stephani.joe8@gmail.com
}

Masuk : 31-03-2018, revisi: 18-01-2019, diterima untuk diterbitkan : 23-01-2019

\begin{abstract}
ABSTRAK
Tujuan penelitian adalah untuk menganalisis pengaruh perilaku oportunistik (diproksikan leverage dan kebijakan dividen) dan mekanisme pengawasan (yang diproksikan dengan kualitas audit dan inkonsistensi informasi) terhadap manajemen laba. Populasi yang dijadikan obyek penelitian berjumlah 43 perusahaan perbankan yang terdaftar di Bursa Efek Indonesia pada tahun 2010-2016. Penelitian ini menggunakan data panel dengan jumlah data observasi sebanyak 70. Data sekunder diolah dengan metode structural equation model dengan pendekatan partial least square. Hasil penelitian menunjukkan bahwa leverage dan kebijakan dividen merupakan perilaku oportunistik yang mempengaruhi positif signifikan terhadap manajemen laba. Kualitas audit dan inkonsistensi informasi nonkeuangan berhubungan positif dengan mekanisme pengawasan. Mekanisme pengawasan beserta indikatornya mempengaruhi positif signifikan terhadap manajemen laba pada bank umum konvensional.
\end{abstract}

Kata kunci: Manajemen Laba, Leverage, Kebijakan Dividen, Kualitas Audit, Informasi Nonkeuangan.

\section{ABSTRACT}

The purpose of this study is to analyze the predictive effect of opportunistic behavior (proxied by leverage and dividend policy) and monitoring mechanism (proxied by audit quality and inconsistency of nonfinancial information) on earnings management. Population of this reseacrh taken as the object of observation amounted to 43 banking firms listed in Indonesia Stock Exchange in the period 2010 - 2016. This research is using panel data with total data amounted to 70 firm-years observation. Secondary data is processed with structural equation model method with partial least square approach. The result showed leverage and dividend policy are opportunistic behaviours that impact positively and significant on earnings management. Audit quality and inconsistency of nonfinancial information are significant indicators of monitoring mechanism. Monitoring mechanism and its indicators have positive and significant impact on earnings management in Conventional Commercial Banks.

Keywords: Earnings Management, Leverage, Dividend Policy, Audit Quality, Nonfinancial Information.

\section{PENDAHULUAN}

\section{Latar Belakang}

Salah satu informasi penting dalam laporan keuangan adalah laba. Laba dalam laporan keuangan menggambarkan efektivitas pengelolaan sumber daya oleh entitas serta pelaksanaan aktivitas yang bernilai tambah untuk menciptakan nilai.

Adanya pemisahan fungsi pemilik perusahaan dengan pengelola perusahaan seringkali menimbulkan konflik kepentingan. Konflik kepentingan ini memicu terjadinya manipulasi informasi keuangan karena principal sebagai pemilik modal ingin memperoleh pengembalian yang singkat dan agent sebagai pengelola modal bertujuan untuk memenuhi kemakmuran pribadi. Manajer sebagai agent memanfaatkan kondisi asimetri informasi antara agent dan principal untuk menampilkan informasi laba dalam laporan keuangan yang paling menguntungkan bagi dirinya. 
Praktik manajemen laba dapat mengakibatkan penurunan kualitas informasi yang diterima pembaca laporan keuangan. Informasi keuangan menjadi tidak dapat diandalkan dan tidak mencerminkan kondisi perusahaan yang sesungguhnya. Hal ini mengakibatkan pengambilan keputusan mungkin menjadi tidak tepat karena informasi yang menjadi dasar pertimbangan telah terdistorsi. Selain itu, praktik manajemen laba yang dilakukan perusahaan juga berdampak pada meningkatnya crash risk of stock price. Hal ini terjadi karena melalui praktik manajemen laba, manajer menyembunyikan berita buruk terkait kinerja perusahaan. Jika praktik ini dilanjutkan, maka kinerja buruk tersebut akan terus terakumulasi.

Penelitian terhadap faktor -faktor yang mempengaruhi manajemen laba masih banyak dilakukan hingga saat ini. Hal ini dikarenakan masih terdapat perbedaan pandangan mengenai legalitas manajemen laba. Dari berbagai penelitian yang dilakukan, belum ditemukan hasil yang konsisten terkait faktor-faktor yang mendorong dan menghambat praktik manajemen laba.

Penelitian pada perusahaan syariah di Malaysia, perusahaan manufaktur di Indonesia, serta perusahaan perbankan di Jordania membuktikan bahwa leverage mempengaruhi positif tetapi tidak signifikan terhadap manajemen laba. Di sisi lain, leverage terbukti secara empiris mempengaruhi manajemen laba secara positif dan signifikan. Ketika perusahaan memperoleh pinjaman, kreditor akan mengawasi kinerja manajer untuk memastikan bahwa pinjaman yang diberikan dapat tertagih. Dengan demikian, ruang gerak manajer untuk melakukan manipulasi informasi menjadi lebih kecil (Suffian et al, 2015; Suriyani et al, 2015; Uwuigbe et al, 2015; Nurdiniah dan Herlina, 2015; Nawaiseh, 2016; Charfeddine et al, 2013; Hamid et al, 2014; Fei, 2015; Ghazali et al, 2015; Gombola et al, 2016).

Kebijakan dividen secara empiris terbukti merupakan insentif atas praktik manajemen laba di perusahaan karena manajer harus memenuhi harapan pemegang saham terkait jumlah dividen yang akan dibagikan perusahaan. Di sisi lain, kebijakan dividen juga dapat dijadikan sebagai mekanisme pengawasan terhadap tindakan oportunistik manajer karena pembagian dividen mencegah penyalahgunaan kelebihan dana oleh manajer. Selain itu, pembagian kelebihan dana kepada pemegang saham merupakan salah satu upaya untuk mengurangi masalah keagenan. Pada perusahaan perbankan di Tunisia, kebijakan dividen justru tidak mempengaruhi praktik manajemen laba secara signifikan karena pembagian dividen pada perusahaan perbankan bukan faktor yang signfikan bagi pemegang saham. Pemegang saham cenderung menggunakan kelebihan dana untuk ekspansi bank daripada dibagikan dalam bentuk dividen (Isahak et al, 2011; Tong dan Miao, 2011; Lin et al, 2014; Noor et al, 2015; Charfeddine et al, 2013; He et al, 2015; dan Costa et al, 2016; Abaoub et al, 2013).

Ketidakkonsistenan hasil penelitian juga ditunjukkan pada faktor kualitas audit. Secara empiris, kualitas audit dapat menjadi alat pengawasan yang efektif terhadap manajemen laba di perusahaan di kawasan Asia Pasifik. Penelitian yang dilakukan terhadap perusahaan di Tunisia dan Perancis menunjukkan hasil yang kontras. Kualitas audit eksternal secara empiris tidak terbukti menjadi alat pengawasan yang efektif karena peningkatan fee audit tidak serta merta mencerminkan peningkatan kualitas audit, tetapi justru dapat mengganggu independensi auditor. Akibatnya pengawasan terhadap manajer menjadi kurang efektif. (Astami et al, 2016; Nekhili et al, 2016; Nawaiseh, 2016; Charfeddine et al, 2016; Amar dan Chabchoub, 2016).

Selain kualitas audit, informasi nonkeuangan juga merupakan alat yang dapat digunakan untuk mengawasi tindakan manajer dalam mengelola perusahaan. Ketidakkonsistenan informasi keuangan dan informasi nonkeuangan dapat menjadi indikasi terjadinya manajemen laba di 
perusahaan. Sayangnya, faktor ini masih jarang diteliti.

Berdasarkan latar belakang tersebut, maka penelitian ini dilakukan untuk untuk membuktikan secara empiris, mengkaji mengapa dan menjelaskan besarnya hubungan antara leverage dan kebijakan dividen dengan perilaku oportunistik, hubungan kualitas audit dan inkonsistensi informasi nonkeuangan dengan mekanisme pengawasan, serta pengaruh perilaku oportunistik dan mekansime pengawasan terhadap manajemen laba pada bank umum konvensional yang terdaftar di BEI tahun 2010-2016.

\section{Kajian Teori}

Teori yang banyak digunakan untuk menjelaskan konflik kepentingan antara principal dan agent adalah Teori Agensi yang dikembangkan oleh Jensen dan Meckeling (1976). Menurut teori ini, dalam mengelola perusahaan, terdapat hubungan agensi dimana suatu pihak sebagai principal memberikan wewenang kepada pihak lain sebagai agent untuk melakukan pekerjaan dan mengambil keputusan atas nama principal. Nyatanya, kedua pihak mempunyai kepentingan yang berbeda. Akibatnya, agent mungkin tidak akan bertindak sepenuhnya untuk memenuhi kepentingan yang didelegasikan oleh principal sehingga timbul masalah keagenan.

Leverage merupakan salah satu faktor yang mendorong manajer berperilaku oportunistik dan melakukan praktik manajemen laba. Hal ini dapat dijelaskan melalui debt-equity hypotheses. Ketika perusahaan mencari pendanaan melalui utang, manajer akan berupaya memilih metode akuntansi yang dapat menampilkan figur laporan keuangan yang menguntungkan. Hal ini dilakukan untuk meyakinkan kreditor bahwa perusahaan mampu memenuhi setiap kewajiban dalam rangka memperoleh pendanaan tersebut. Selain itu, tampilan laporan keuangan yang menguntungkan juga memberikan posisi bargaining power yang lebih tinggi bagi perusahaan dalam proses negosiasi pendanaan. Tingkat leverage yang tinggi juga meningkatnya risiko perusahaan mengalami financial distress. Pada institusi keuangan, khususnya perbankan, terdapat berbagai regulasi yang mengatur mengenai kecukupan modal perbankan untuk memastikan bahwa perusahaan dapat mengatasi risiko kredit yang ditimbulkan dari peningkatan leverage. Adanya kewajiban untuk mengatasi risiko kredit tersebut membuat manajer termotivasi untuk melakukan manajemen laba agar laporan keuangan perusahaan memberikan figur kinerja perusahaan yang baik. (Suriyani et al, 2015; Charfeddine et al, 2013; Moghaddam dan Abbaspour, 2017).

Kebijakan dividen dapat menjadi faktor pendorong manajer berperilaku oportunistik. Hal ini terjadi karena adanya ekspektasi dari pemegang saham terkait jumlah pembagian dividen. Ketika perusahaan tidak mampu memenuhi ekspektasi dividen, terdapat perubahan yang signifikan atas harga pasar saham. Oleh karena itu, manajer berupaya melakukan berbagai cara untuk memenuhi ekspektasi pemegang saham terkait pembagian dividen (Isahak et al, 2011; Abaoub et al, 2013; Norden dan Stoian, 2013 dan Lin et al, 2014).

Fee audit yang tinggi merupakan cerminan dari biaya audit yang tinggi karena auditor menyediakan jasa yang lebih berkualitas. Ketika KAP mempekerjakan tenaga ahli yang lebih kompeten dalam penugasan, maka biaya audit pun akan meningkat sehingga berdampak pada peningkatan fee audit yang dikenakan ke klien. Selain itu, KAP juga dapat mengenakan fee audit yang tinggi karena sudah memiliki reputasi yang terpercaya mengenai kualitas jasa yang dihasilkan. Hal ini terlihat bahwa auditor dari KAP Big 4 pada umumnya dapat mengenakan fee audit yang lebih tinggi dibanding KAP lain karena mereka memiliki reputasi yang lebih baik terkait kualitas jasa yang diberikan (Okolie, 2014; Muzatko dan Teclezion, 2016). 
Tekanan untuk memenuhi kepentingan berbagai stakeholder dan tekanan kompetisi pasar menjadi salah satu faktor yang mendorong manajemen untuk memanipulasi informasi yang disajikan ke pengguna laporan. Sayangnya, informasi nonkeuangan cenderung lebih sulit dimanipulasi oleh manajer. Ketika ditemukan adanya inkonsistensi antara informasi keuangan dan informasi nonkeuangan, kondisi ini dapat menjadi red flag bahwa manajer tidak melaporkan kondisi keuangan perusahaan yang sebenarnya. Selain tekanan, motivasi untuk memperoleh bonus juga menjadi faktor pendorong dilakukannya manipulasi informasi. Ketika pengukuran kinerja manajer didasarkan hanya pada informasi keuangan saja, manajer terdorong untuk melakukan manajemen laba agar kinerjanya terlihat bagus dan manajer memperoleh bonus yang dijanjikan. (Hassabelnaby et al, 2008; Brazel et al, 2009; Bukit dan Nasution, 2015; Nurdiniah dan Herlina, 2015).

Kerangka pemikiran dalam penelitian ini seperti digambarkan berikut ini:

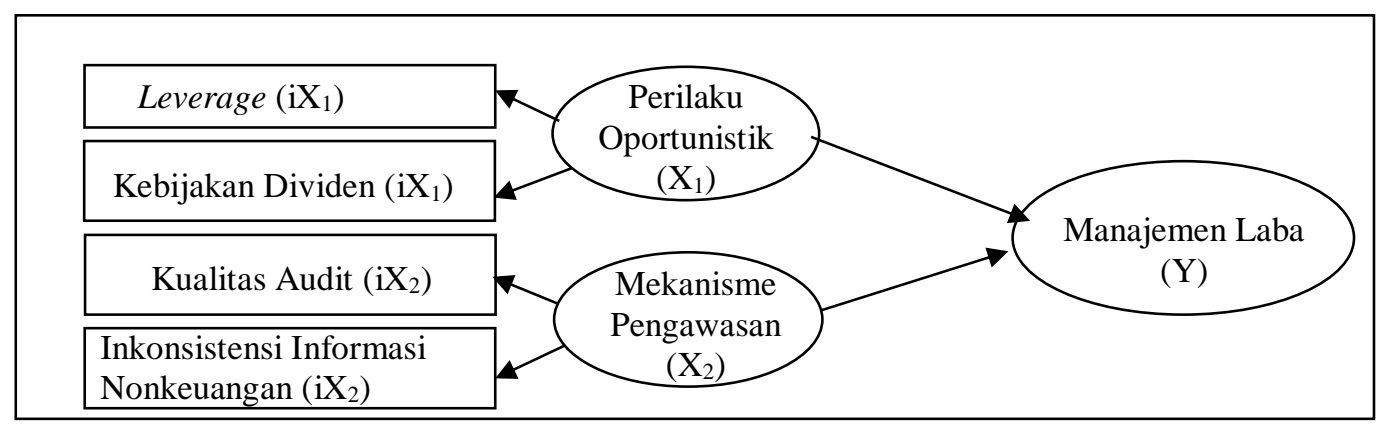

Gambar 1. Kerangka Pemikiran

Sumber: Data Olahan Penulis (2017)

Berdasarkan pembahasan mengenai keterkaitan antarvariabel, maka dapat dirumuskan hipotesis penelitian yaitu:

$\mathrm{H}_{1}$ : Leverage berhubungan positif dengan perilaku oportunistik pada bank umum konvensional yang terdaftar di BEI tahun 2010 - 2016.

$\mathrm{H}_{2}$ : Kebijakan dividen berhubungan positif dengan perilaku oportunistik pada bank umum konvensional yang terdaftar di BEI tahun 2010 - 2016.

$\mathrm{H}_{3}$ : Perilaku oportunistik beserta indikatornya mempengaruhi positif manajemen laba pada bank umum konvensional yang terdaftar di BEI tahun 2010 - 2016.

$\mathrm{H}_{4}$ : Kualitas audit berhubungan positif dengan mekanisme pengawasan pada bank umum konvensional yang terdaftar di BEI tahun 2010 - 2016.

$\mathrm{H}_{5}$ : Inkonsistensi informasi nonkeuangan berhubungan positif dengan

mekanisme pengawasan pada bank umum konvensional yang terdaftar di BEI tahun 2010 2016.

$\mathrm{H}_{6}$ : Mekanisme pengawasan beserta indikatornya mempengaruhi negatif manajemen laba pada bank umum konvensional yang terdaftar di BEI tahun 2010 - 2016.

\section{METODE PENELITIAN}

Penelitian ini menggunakan desain penelitian data panel. Subjek penelitian ini adalah perusahaan perbankan yang terdaftar di Bursa Efek Indonesia selama tahun 2010 - 2016. Data yang diteliti merupakan data sekunder yang diperoleh dari berbagai sumber. Populasi dalam penelitian ini adalah perusahaan perbankan konvensional yang terdaftar di Bursa Efek Indonesia (BEI) pada periode 2010-2016. Perusahaan yang dipilih sebagai sampel harus mempunyai data lengkap terkait penelitian. Jumlah data penelitian sebanyak 70 data observasi. Data yang telah dikumpulkan dianalisis dengan teknik partial least square - structural equation 
modeling (PLS-SEM) melalui program SmartPLS versi 2. Analisis ini terdiri dari beberapa tahap diantaranya pengujian outer model, pengujian inner model dan pengujian hipotesis.

Variabel dependen yang diteliti adalah praktik manajemen laba. Pendekatan untuk mengukur manajemen laba dalam penelitian ini menggunakan metode discretionary accrual yaitu:

$$
L L P_{t, 1}=\alpha_{0}+\alpha_{1}\left(\mathrm{NPL}_{\mathrm{t}-1} / \mathrm{TA}_{\mathrm{t}-1}\right)+\alpha_{2}\left(\Delta \mathrm{NPL}_{\mathrm{t}} / \mathrm{TA}_{\mathrm{t}-1}\right)+\alpha_{3}\left(\Delta \mathrm{LOAN}_{\mathrm{t}} / \mathrm{TA}_{\mathrm{t}-1}\right)+\varepsilon_{\mathrm{t}}
$$

Dimana:

$L L P_{t, 1} \quad$ : Penyisihan Cadangan Kerugian Penurunan Nilai periode $\mathrm{t}$

$N P L_{t-1} \quad$ : Total kredit bermasalah periode $\mathrm{t}-1$

$\triangle N P L_{t} \quad$ : Perubahan total kredit bermasalah periode $\mathrm{t}-1 \mathrm{ke} \mathrm{t}$

$\triangle L O A N_{t}$ : Perubahan total kredit periode $\mathrm{t}-1$ ke periode $\mathrm{t}$

$T A_{t-1} \quad:$ Total aset periode $\mathrm{t}-1$

$\varepsilon_{\mathrm{t}} \quad$ : Nilai residual yang menggambarkan proporsi discretionary accruals

Variabel independen yang diteliti adalah perilaku oportunistik dan mekanise pengawasan. Leverage dan kebijakan dividen digunakan sebagai indikator perilaku oportunistik. Kualitas audit dan inkonsistensi informasi nonkeuangan digunakan sebagai indikator mekanisme pengawasan.

Leverage diukur dengan rumus:

$$
\text { DER }=\frac{\text { Total Debt }}{\text { Total Shareholders' } \text { Equity }}
$$

Kebijakan dividen diukur dengan rumus:

$$
\text { Dividend Yield }=\frac{\text { Dividend Per Share }}{\text { Closing Market Price }}
$$

Kualitas audit diukur dengan rumus:

$$
\text { Kualitas Audit }=\text { LnAudit Fee }
$$

Inkonsistensi informasi nonkeuangan diukur dengan rumus:

Inkonsistensi $=\Delta$ Pendapatan $-\Delta$ kapasitas

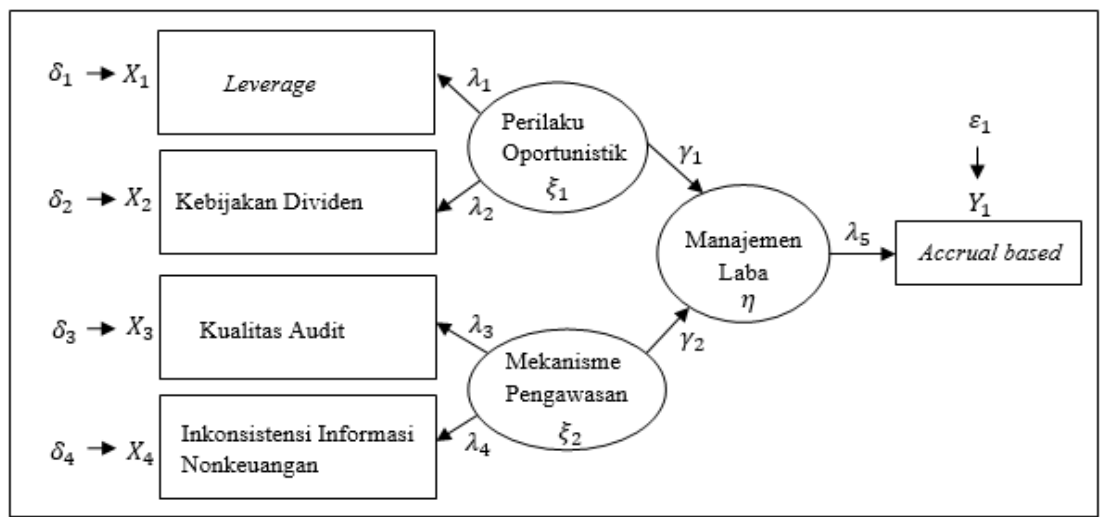

Diagram Jalur

Sumber: Data Olahan Penulis (2017)

\section{HASIL DAN PEMBAHASAN}

\section{Hasil Uji PLS SEM}

Pengujian outer model terdiri dari pengujian composite reliability, indicator reliability, convergent validity, dan discriminant validity. 
Tabel 1 Hasil Pengujian Reliabilitas Komposit (Composite Reliability) Sumber: Output SmartPLS 2, diolah, 2017

\begin{tabular}{|l|c|c|c|}
\hline & $\begin{array}{c}\text { Composite } \\
\text { Reliability }\end{array}$ & Kriteria & Kesimpulan \\
\hline Manajemen Laba & 1.000000 & $\geq 0.60$ & Reliabel \\
\hline Perilaku Oportunistik & 0.654243 & $\geq 0.60$ & Reliabel \\
\hline Mekanisme Pengawasan & 0.750142 & $\geq 0.60$ & Reliabel \\
\hline
\end{tabular}

Tabel 2 Hasil Pengujian Reliabilitas Indikator (Outer Model/ Weights or Loadings) Sumber: Output SmartPLS 2, diolah, 2017

\begin{tabular}{|l|c|c|c|c|c|}
\hline & $\begin{array}{c}\text { Manajemen } \\
\text { Laba }\end{array}$ & $\begin{array}{c}\text { Perilaku } \\
\text { Oportunistik }\end{array}$ & $\begin{array}{c}\text { Mekanisme } \\
\text { Pengawasan }\end{array}$ & Kriteria & Kesimpulan \\
\hline Discretionary LLP & 1.000000 & & & $>0.70$ & Reliabel \\
\hline Leverage & & 0.977030 & & $>0.70$ & Reliabel \\
\hline Kebijakan Dividen & 0.533885 & & $>0.70$ & $\begin{array}{c}\text { Tidak } \\
\text { Reliabel }\end{array}$ \\
\hline Kualitas Audit & & & 0.913033 & $>0.70$ & Reliabel \\
\hline $\begin{array}{l}\text { Inkonsistensi } \\
\text { Informasi } \\
\text { Nonkeuangan }\end{array}$ & & 0.442281 & $>0.70$ & $\begin{array}{c}\text { Tidak } \\
\text { Reliabel }\end{array}$ \\
\hline
\end{tabular}

Tabel 3 Hasil Pengujian Validitas Konvergen (Average Variance Extracted) Sumber: Output SmartPLS 2, diolah, 2017

\begin{tabular}{|l|c|c|c|}
\hline & AVE & Kriteria & Kesimpulan \\
\hline Manajemen Laba & 1.000000 & $>0.5$ & Valid \\
\hline Perilaku Oportunistik & 0.619810 & $>0.5$ & Valid \\
\hline Mekanisme Pengawasan & 0.514621 & $>0.5$ & Valid \\
\hline
\end{tabular}

Tabel 4 Hasil Pengujian Validitas Diskriminan (Cross Loadings)

Sumber: Output SmartPLS 2, diolah, 2017

\begin{tabular}{|l|c|c|c|}
\hline & Manajemen Laba & $\begin{array}{c}\text { Perilaku } \\
\text { Oportunistik }\end{array}$ & $\begin{array}{c}\text { Mekanisme } \\
\text { Pengawasan }\end{array}$ \\
\hline Discretionary LLP & 1.000000 & 0.904406 & -0.230336 \\
\hline Leverage & 0.945281 & 0.977030 & -0.479619 \\
\hline Kebijakan Dividen & 0.238234 & 0.533885 & -0.417233 \\
\hline Kualitas Audit & -0.212652 & -0.497391 & 0.913033 \\
\hline $\begin{array}{l}\text { Inkonsistensi } \\
\text { Informasi } \\
\text { Nonkeuangan }\end{array}$ & -0.096711 & -0.195138 & 0.442281 \\
\hline
\end{tabular}

Tabel 4 menunjukkan bahwa setiap indikator sudah valid karena mempunyai korelasi paling tinggi dengan variabel latennya dibandingkan dengan variabel laten lain

Pengujian inner model dilakukan dengan menganalisis nilai $\mathrm{R}^{2}$ pada Tabel 5 berikut ini. 
Tabel 5 Nilai $\mathrm{R}^{2}$

Sumber: Output SmartPLS 2, diolah, 2017

\begin{tabular}{|c|c|}
\hline Variabel Endogen & $\mathbf{R}^{\mathbf{2}}$ \\
\hline Manajemen Laba & 0.901246 \\
\hline
\end{tabular}

Tabel 5 menunjukkan bahwa 90.12\% variasi manajemen laba pada bank umum konvensional yang terdaftar di BEI selama periode 2010-2016 dijelaskan oleh perilaku oportunistik yang diproksikan dengan leverage dan kebijakan dividen serta mekanisme pengawasan yang diproksikan dengan kualitas audit dan inkonsistensi informasi nonkeuangan. 9.88\% variasinya dijelaskan oleh variabel lain yang tidak termasuk dalam penelitian ini.

Diagram jalur penelitian ini dijelaskan dengan Gambar 2 dibawah ini.

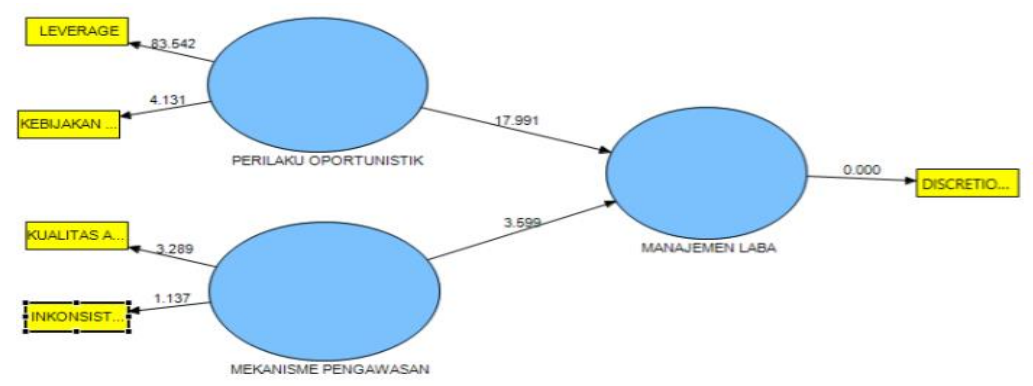

Gambar 2 Diagram Jalur Bootstrapping

Sumber: Output SmartPLS 2, diolah, 2017

Tabel 6 Nilai Outer Weights

Sumber: Output SmartPLS 2, diolah, 2017

\begin{tabular}{|l|c|c|c|}
\hline \multirow{2}{*}{} & \multicolumn{3}{|c|}{ Original Sample (O) } \\
\cline { 2 - 4 } & $\begin{array}{c}\text { Perilaku } \\
\text { Oportunistik }\end{array}$ & $\begin{array}{c}\text { Mekanisme } \\
\text { Pengawasan }\end{array}$ & $\begin{array}{c}\text { Manajemen } \\
\text { Laba }\end{array}$ \\
\hline Leverage & 0.899619 & & \\
\hline Kebijakan Dividen & 0.226726 & & \\
\hline Kualitas Audit & & 0.897525 & \\
\hline Inkonsistensi Informasi Nonkeuangan & & 0.408180 & \\
\hline Perilaku Oportunistik & & & 1.082937 \\
\hline Mekanisme Pengawasan & & & 0.339367 \\
\hline
\end{tabular}

\section{Diskusi}

Berdasarkan pengujian hipotesis, $\mathrm{H}_{1}$ diterima, artinya leverage berhubungan positif signifikan dengan perilaku oportunistik pada bank umum konvensional di BEI tahun 2010 - 2016. Hasil penelitian ini dapat dijelaskan berdasarkan debt covenant hypothesis. Ketika perusahaan mempunyai tingkat leverage yang tinggi, manajer cenderung memilih metode akuntansi yang dapat menampilkan kinerja keuangan perusahaan yang baik. Dalam hal ini, manajer berupaya meyakinkan kreditur bahwa perusahaan mempunyai kemampuan finansial yang memadai untuk memenuhi kewajiban atas utang yang diperoleh.

Hasil pengujian $\mathrm{H}_{2}$ menunjukkan bahwa secara empiris kebijakan dividen berhubungan positif dengan perilaku oportunistik pada bank umum konvensional yang terdaftar di BEI tahun 2010 2016. Ketika pemegang saham mempunyai ekspektasi jumlah dividen yang akan dibagikan, 
manajer cenderung berperilaku oportunistik karena berusaha memenuhi ekspektasi tersebut. Dengan terpenuhinya ekspektasi pemegang saham, manajer berupaya menjaga harga saham perusahaan karena pemegang saham percaya bahwa mereka dapat meperoleh pengembalian yang diharapkan dari investasinya ke perusahaan.

Hasil pengujian $\mathrm{H}_{3}$ menunjukkan bahwa secara empiris, perilaku oportunistik beserta indikatornya yakni leverage dan kebijakan dividen mempengaruhi manajemen laba secara positif pada bank umum konvensional yang terdaftar di BEI tahun 2010 - 2016. Hal ini karena manajer memanfaatkan celah-celah yang ada pada kebijakan dan standar akuntansi untuk menampilkan kinerja keuangan terbaik perusahaan sehingga dapat memenuhi keinginan baik kreditur, regulator maupun pemegang saham. Ketika manajer dapat memenuhi ekspektasi para pemangku kepentingan, manajer dianggap sebagai agent dengan kinerja yang baik dalam mengelola perusahaan. Hal ini merupakan suatu keuntungan karena manajer dapat memperoleh insentif atau bonus atas kinerjanya.

Hasil penelitian $\mathrm{H}_{4}$ menunjukkan hubungan yang positif dan signifikan antara kualitas audit dengan mekanisme pengawasan pada bank umum konvensional yang terdaftar di BEI tahun 2010 - 2016. Hasil penelitian ini sesuai dengan teori yang menjelaskan bahwa peningkatan fee audit terjadi karena KAP menugaskan personil yang lebih berkompeten sehingga meningkatkan biaya audit. Selain itu, suatu KAP dapat mengenakan fee audit yang tinggi karena sudah memiliki reputasi yang baik terkait kualitas jasa yang diberikan. Dengan demikian, peningkatan kualitas audit dapat meningkatkan efektifitas auditor eksternal sebagai mekanisme pengawasan eksternal yang independen.

$\mathrm{H}_{5}$ dalam penelitian ini ditolak, artinya inkonsistensi informasi nonkeuangan tidak berhubungan positif dengan mekanisme pengawasan pada bank umum konvensional yang terdaftar di BEI tahun 2010 - 2016. Secara teori, informasi nonkeuangan dapat dijadikan sebagai alat untuk membedakan perusahaan yang melakukan fraud dengan perusahaan yang tidak melakukan fraud. Sayangnya secara empiris, teori ini terbukti tidak dapat digeneralisasi ke bank umum konvensional yang terdaftar di BEI tahun 2010 - 2016. Proses bisnis yang berbeda menimbulkan perilaku manajer yang berbeda.

Hasil pengujian H6 ditolak karena secara empiris mekanisme pengawasan beserta indikatornya tidak mempunyai pengaruh negatif terhadap manajemen laba pada bank umum konvensional yang terdaftar di BEI tahun 2010 - 2016. Hal ini berarti kualitas audit dan inkonsistensi informasi nonkeuangan tidak dapat diterapkan untuk mengurangi manajemen laba dalam industri perbankan yang terdaftar di Bursa Efek Indonesia selama periode 2010-2016. Peningkatan fee audit tidak hanya mencerminkan peningkatan kualitas audit, tetapi juga dapat mengganggu independensi auditor. Di Indonesia, Bank Indonesia mulai menerapkan konsep branchless banking sejak periode 2013-2016. Oleh karena itu, kapasitas perusahaan yang digambarkan dari pertumbuhan jumlah jaringan outlet tidak dapat digunakan sebagai satusatunya informasi nonkeuangan untuk memverifikasi ketepatan penyajian informasi pendapatan dan laba perusahaan perbankan yang terdaftar di Bursa Efek Indonesia selama periode 20102016.

\section{KESIMPULAN DAN SARAN}

Hasil penelitian menunjukkan bahwa leverage dan kebijakan dividen berhubungan positif dengan perilaku oportunistik. Perilaku oportunistik beserta indikatornya mempengaruhi positif 
manajemen laba pada bank umum konvensional yang terdaftar di BEI tahun 2010 - 2016 . Kualitas audit berhubungan positif dengan mekanisme pengawasan sedangkan inkonsistensi informasi nonkeuangan berhubungan negatif dengan mekanisme pegawasan. Mekanisme pengawasan beserta indikatornya juga tidak mempengaruhi negatif manajemen laba pada bank umum konvensional yang terdaftar di BEI tahun 2010 - 2016.

Keterbatasan dalam penelitian ini adalah pemilihan sampel dengan teknik nonprobability sampling sehingga hasilnya tidak dapat digeneralisasi. Selain itu, pengukuran informasi nonkeuangan kurang relevan dengan industri perbankan Indonesia yaitu dengan tingkat perubahan jumlah outlet.

Penelitian berikutnya diharapkan dapat memperluas unit observasi sehingga hasil penelitian dapat digeneralisasi terhadap seluruh perusahaan perbankan yang ada di Indonesia. Selain itu, sebaiknya penelitian selanjutnya menambahkan berbagai variabel untuk memberikan gambaran yang lebih komprehensif terkait praktik manajemen laba.

\section{REFERENSI}

Abaoub, E., Homrani, K., \& Gamra, S. B. (2013). The determinants of earnings management: Empirical evidence in the Tunisian banking industry (1999-2010). Journal of Business Studies Quarterly, 4(3): 62-72.

Amar, A. B., \& Chabchoub, M. (2016). Audit quality and earnings management to avoid losses and earnings decreases: The French case. International Journal of Academic Research in Accounting, Finance and Management Sciences, 6(4): 20-27. doi: 10.6007/IJARAFMS/v6-i4/2285.

Astami, E. W., Rusmin, R., Hartadi, B., \& Evans, J. (2017). The role of audit quality and culture influence on earnings management in companies with excessive free cash flow: Evidence from the Asia-Pacific region. International Journal of Accounting and Information Management, 25(1): 21-42. doi: 10.1108/IJAIM-05-2016-0059.

Brazel, J. F., Jones, K. L., Zimbelman, M. F. (2009). Using nonfinancial measures to assess fraud risk. Journal of Accounting Research 47(5): 1135-1166.

Bukit, R. B., \& Nasution, F. B. (2015). Employee diff, free cash flow, corporate governance and earnings management. Procedia - Social and Behavioral Sciences 211: 585-594. doi: 10.1016/j.sbspro.2015.11.077. Retrieved from http://www.sciencedirect.com

Charfeddine, L., Riahi, R., \& Omri, A. (2013). The determinants of earnings management in developing countries: A study in the Tunisian context.

Costa, L., Cerqueira, A., \& Brandao, E. (2016). The impact of financial crisis on earnings management: Evidence from EU-25.

Fei, C. C. (2015). The impact of managerial opportunism on earnings reliability. International Journal of Economics and Finance, 7(10): 222-234. doi:10.5539/ijef.v7n10p222. Retreived from http://dx.doi.org/10.5539/ijef.v7n10p222

Ghazali, A. W., Shafie, N. A., \& Sanusi, Z. M. (2015). Earnings management: an analysis of opportunistic behavior, monitoring mechanism and financial distress. Procedia Economics and Finance, 28: 190-201.

Gombola, M. J., Ho., A. Y. F., Huang, C. C. (2016). The effect of leverage and liquidity on earnings and capital management: evidence from U.S commercial bank. International Review of Economics and Finance 43: 35-58.

Hamid, F. A., Eddine, C. O. A., Ayedh, A. M., \& Echchabi, A. (2014). Firms' financial and corporate governance characteristics association with earnings management practices: A meta-analysis approach. Journal of Economics and Business, XII(2): 49-72. 
HassabElnaby, H. R., Mohammad, E., Said, A. A. (2008). Nonfinancial measures and earnings management.

He, W., Ng, L. N., Zaiats, N. S., \& Zhang, B. (2015). Dividend policy and earnings management across countries. Journal of Corporate Finance, 42: 267-286.

Isahak, M. S., Sanusi, Z. M., \& Sulong, Z. (2011). External agency monitoring mechanisms and earnings management for improved financial reporting. International Journal of Business and Management Science, 4(2): 129-145

Lin, S. H., Lin, L. H., Lai, H. H., \& Tu, C. C. (2014). Expected dividend and earnings management: Evidence from Taiwan. International Journal of Organizational Innovation, 7(1): 202-211.

Moghaddam, A., Abbasour, N. (2017). The effect of leverage and liquidity ratio on earnings management and capital of bank listed on Tehran Stock Exchange. International Review of Management and Marketing 7(4): 99-107.

Muzatko, S., Teclezion, M. (2016). The relationship between audit fee and earnings quality of financial institutions. Journal of Accounting and Finance 16(5): 20-31

Nawaiseh, M. E., (2016). Can earnings management be influenced by audit quality? International Journal of Finance and Accounting, 5(4): 209-219.

Nekhili, M., Amar, I. F. B., Chtioui, T., \& Lakhal, F. (2016). Free cash flow and earnings management: The moderating role of governance and ownership. The Journal of Applied Business Research, 32(1): 255-268.

Nurdiniah, D., \& Herlina, L. (2015). Analysis of factors affecting the motivation of earnings management in manufacturing listed in Indonesia stock exchange. Research Journal of Finance and Accounting, 6(3): 100-108.

Noor, M. F. D., Sanusia, Z. M., Heang, L. T., Iskandar, T. M., \& Isa, Y. M. (2015). Fraud motives and opportunities factors on earnings manipulations. Procedia Economics and Finance, 28: 126-135.

Norden, L., Stoian, A. (2013). Bank earnings management through loan loss provisions: a double-edge sword? DNB Working Paper 404: 1-46.

Okolie, A. O. (2014). Auditor tenure, auditor independence and accrual-based earnings management of quoted companies in Nigeria. European Journal of Accounting Auditing and Finance Research, 2(2): 63-90.

Suffian, M. T. M., Sanusi, Z. M., Osman, A. M., \& Azhari, M. I. M. (2015). Manipulation of earnings: The pressure of opportunistic behavior and monitoring mechanisms in Malaysian shariah-complaint companies. Procedia Economics and Finance, 31: 213-227.

Suriyani, P. P., Yuniarta, G. A., \& Wikrama, A. T. A. (2015). Faktor-faktor yang mempengaruhi manajemen laba (studi empiris pada perusahaan manufaktur yang terdaftar di BEI tahun 2008-2013). Jurnal Akuntansi Program S1, 3.

Tong, Y. H., \& Miao, B. (2011). Are dividends associated with the quality of earnings. Accounting Horizon, 25(1): 183-205. doi: 10.2308/acch.2011.25.1.183. Retrieved from http://www.aaapubs.org

Uwuigbe, U. Uwuigbe, O. R., Bernard, O. (2015). Assessment of the effect of firm's characteristics on earnings management of listed firms in Nigeria. Asian Economic and Financial Review, 5(2): 218-228. 